\title{
Isolation and Characterization of Rhizobium Associated with Root Nodules of Dalbergia sissoo
}

\author{
Meenakshi Dhiman*, Vinay Kumar Dhiman, Neerja Rana and Bhawna Dipta
}

${ }^{1}$ Microbiology Division, ${ }^{2}$ Department of Basic Sciences, Dr. Yashwant Singh Parmar University of Horticulture and Forestry, Nauni, Solan-173230, Himachal Pradesh, India

*Corresponding author

\section{Keywords}

Isolation, Characterization, Rhizobia, Biofertilizers, Nitrogen fixation

Article Info

Accepted:

15 January 2019

Available Online:

10 February 2019

\section{A B S T R A C T}

A study was conducted to isolate and characterize the rhizobia from the root nodule of Dalbergia sissoo from five different sites of Himachal Pradesh (Bilaspur, Solan, Hamirpur, Kangra and Una) and Uttrakhand (Rishikesh, Nainital, Haridwar, Dehradun and Udham Singh Nagar). A total of 79 bacterial isolates were isolated from root nodule of Dalbergia sissoo on YEMA media after 3 days of incubation at $37^{\circ} \mathrm{C}$ by serial dilution method. Out of 79 isolates only 38 isolates were identified as rhizobia on the basis of authentication test (Congo red test, Bromothymol blue test and Plant infection test). Thirty eight strains were characterized on the basis of biochemical characterization. On the basis of morphological properties all the isolates were round and slimy white with raised elevation and smooth surface indicating rhizobia. In Gram's reaction they were pink, rod in shape indicating gram negative bacteria. Only two rhizobial isolates DBD1 and DRT5 were selected on the basis of plant growth promoting traits (P-solubilization, Nitrogen fixation, Siderophore production, HCN production and Biocontrol activity). These two rhizobial isolates may be useful to increase the symbiotic nitrogen fixation in legume tree and can be used as potential biofertilizer owing to their plant growth promoting characters.

\section{Introduction}

Low fertility is an important problem in establishing vegetation on the degraded lands. The nitrogen is generally deficient in these lands; the fertility of such soils can be maintained by supplementing fertilizers especially the nitrogen. The nitrogen fertilizer is not only costly and scarce, but also lost rapidly due to leaching, runoff and volatilization, causing water and atmospheric pollution.

Biological Nitrogen Fixation is a natural process where certain bacteria and leguminous plants with nodules in their root systems are able to convert the nitrogen gas into a form that is usable for plant life. The ability to fix atmospheric nitrogen into a form that can be used for plant growth is confined 
to bacteria and cyanobacteria. Plants fix nitrogen only by virtue of associations with these simple organisms. The best-known associations are the symbioses of Rhizobium bacteria with legumes. Nitrogen fixing leguminous plants not only supports plant growth independent of mineral nitrogen in the soil but also improve soil nitrogen status for associated crops by the residues of these plants.

Bacteria involved in symbiotic nitrogen fixation belong to genera Rhizobium and Bradyrhizobium. Rhizobia forms tumor like swellings called nodules on the root surface of host plant. Rhizobia inside the nodules absorb air from the soil and convert gaseous nitrogen into ammonia. This association between the host plant and rhizobia is mutually beneficial.

The process of BNF is strongly related to the physiological status of host plant and rhizobial strains. The different responses of rhizobial strains to various factors considered as basic criteria for differentiation and identification of these bacteria (Zahran et al., 2012). Rhizobia adapt themselves in different environment including soil, rhizosphere and grow within legume roots, where they fix nitrogen (Ghosh and Maiti, 2016). They can trigger leguminous host plants to form root nodules.

Biofertilizer enhance plant growth and productivity and has globally been acknowledged as a substitute of chemical fertilizer. Rhizobacteria efficiently inhabit plant root and boost plant growth by production of various plant growth hormones, P-solubilizing activity, N2 fixation and biological control activity (Deshwal et al., 2003).

A well conventional practice for maintaining soil fertility has been the cultivation of leguminous plants which replenish atmospheric nitrogen through symbiosis with rhizobia in rotation with non leguminous plants.

\section{Materials and Methods}

\section{Sample collection and sowing}

Seeds were collected from 15 to 25 year old matured and healthy trees of Dalbergia sissoo from different geographic locations in Himachal Pradesh (Bilaspur, Solan, Hamirpur, Kangra and Una) and Uttarakhand (Rishikesh, Nainital, Haridwar, Dehradun and Udham Singh Nagar).

In each location three representative sites were selected and three plant samples were collected from each site. Seeds from different sources were kept in germinator at $25-30^{\circ} \mathrm{C}$ for germination and then sown in the poly bags (mixture of soil, sand and farm yard manure in 2:1:1 ratio). The seeds from different locations were sown in nursery intended for evaluating their growth.

\section{Isolation of Rhizobium from root nodules}

Healthy nodules were isolated from the six month old D. sissoo seedlings grown under net house conditions. The nodules were washed in tap water to remove the adhering soil particles on its surface. Nodules were dipped in $0.1 \%$ mercuric chloride $\left(\mathrm{HgCl}_{2}\right)$ solution for 30 second and then washed successively eight to ten times with sterilized distilled water to remove the traces of $\mathrm{HgCl}_{2}$.

Surface sterilized nodules were crushed in sterilized distilled water by glass rod to obtain a milky suspension of bacteriods. The suspension was streaked on YEMA medium and incubated at $28 \pm 2^{\circ} \mathrm{C}$ for $2-5$ days. The growth on YEMA medium was counted and expressed as cfu/g. Isolates obtained from nodules of Dalbergia sissoo were purified on YEMA medium by streak plate method. 


\section{Authentication}

\section{Congo red test}

All the purified rhizobial isolates were streaked on CRYEMA medium and were observed for absorption of congo red dye (Vincent, 1970).

\section{Bromothymol blue test}

The YEMA medium containing bromothymol blue was streaked with isolated strains and was observed either for yellow colour due to production of acids or blue colour due to production of alkali (Norris, 1965).

\section{Hofer's alkaline test}

This test is based on the fact that Rhizobium is unable to grow at higher $\mathrm{pH} 11.0$ on yeast extract mannitol broth (Hofer, 1935).

\section{Ketolactose agar test}

Ketolactose agar plates were streaked with isolated microbes. After incubation for 4-6 days at $28 \pm 2{ }^{\circ} \mathrm{C}$, the plates were flooded with Benedict's solution. This test is based on the fact that rhizobium is unable to utilize the lactose (Bernaerts and Deley, 1963).

\section{Plant infection test}

The different isolates were tested for their ability to nodulate Dalbergia sissoo plants grown in plastic pots. Seeds of Dalbergia sissoo were inoculated with Rhizobium isolates by soaking seeds. Plants were carefully uprooted after 75 days and observed for nodulation.

\section{Morphological characterization}

Morphological characteristics of isolates including colony color, opacity, form, elevation, margin, surface, texture, motility, shape, arrangement, gram's reaction, endospore staining, capsular staining were determined by observing the colonies on YEMA plates

\section{Physiological characterization}

Separate experiments were performed which include $\mathrm{pH}$, temperature, $\mathrm{NaCl}$ concentration, incubation period for optimization conditions for growth of selected rhizobial isolates.

\section{Biochemical characterization}

Indole test, Methyl red test, Citrate utilization, Starch hydrolysis, Casein hydrolysis, Gelatin hydrolysis, Hydrogen sulphide production, Catalase test, Voges Proskauer test, Urease test, Carbohydrates fermentation, Ammonia production test, Cellulase test.

\section{Results and Discussion}

\section{Isolation of Rhizobia from root nodules of Dalbergia sissoo}

The isolation of rhizobia was carried out from the root nodules of six month old $D$. sissoo seedlings grown under net house conditions. The growth on YEMA medium was counted and expressed as cfu/g. A total of 38 bacterial isolates were isolated from 5 different sites of Himachal Pradesh. A great variation in the rhizobial population colonizing the roots of $D$. sissoo seedlings were noticed (Table 1$)$. The maximum rhizobial count $\left(8.53 \times 10^{3} \mathrm{cfu} / \mathrm{g}\right.$ root) and $\left(8.14 \times 10^{3} \mathrm{cfu} / \mathrm{g}\right.$ root $)$ on YEMA medium were observed with Hamirpur and Haridwar seed sources, respectively. Whereas, minimum rhizobial count $\left(6.85 \times 10^{3}\right.$ $\mathrm{cfu} / \mathrm{g}$ root $)$ and $\left(6.73 \times 10^{3} \mathrm{cfu} / \mathrm{g}\right.$ root $)$ were recorded in Solan seed source of Himachal Pradesh and Rishikesh seed source of Uttrakhand, respectively. The variation in population may arise due to difference in soil 
physio-chemical properties, environmental conditions, root exudates and the plant age (Wieland et al., 2001). Balota and Chaves (2011) and Zhou et al., (2017) have also reported similar results.

Authentication of rhizobia isolated from Dalbergia sissoo root nodules

A total of 38 rhizobial isolates from Dalbergia sissoo root nodules of Himachal Pradesh were isolated and screened for different authentication tests viz. congo red test, bromothymol blue test, growth in Hofer's alkaline broth, ketolactose medium and plant infection test. All the 38 isolates were found negative for congo red test on congo red YEMA medium. The results are supported by Mahmood and Athar (2008) who reported negative results for congo red medium. None of the isolate showed growth on Hofer's alkaline broth and did not utilize lactose and peptone after incubation period at $28 \pm 2^{\circ} \mathrm{C}$. Out of these 38 isolates, 28 isolates from Himachal Pradesh showed yellow colored acid producers colonies enriched with bromothymol after incubation for 3-5 days at
$28 \pm 2^{\circ} \mathrm{C}$. Fast grower takes $3-5$ days of incubation to grow. The plant infection test also revealed that only 26 out of 38 isolates nodulated the Dalbergia seedlings after 75 days of inoculation and these isolates were tentatively confirmed as Rhizobium spp. (Table 2). Similar results were observed in the findings of Agrawal et al., (2012); Deshwal and Chubey (2014) and Dipta et al., (2017) reporting absence of congo red dye absorption, absence of growth in Hofer's alkaline broth and did not utilize lactose or peptone.

\section{Morphological characterization of selected rhizobial isolates}

The results presented in (Table 3) the colony morphology, Gram's reaction and cell shape of selected rhizobial isolates. The isolates produced opaque, nearly round and gummy colonies with raised elevation and smooth surface, which indicated it as rhizobia spp. The Gram's reaction indicated them to be gram negative rods. They were motile, non endospore forming capsulated microbes.

Table.1 Rhizobial population from root nodules of D.sissoo

\begin{tabular}{|c|c|c|}
\hline \multirow{4}{*}{ Himachal Pradesh } & Sites & $\begin{array}{c}\text { Rhizobial population } \\
\left(\mathbf{1 0}^{\mathbf{3}} \mathbf{c f u} / \mathbf{g} \text { soil) }\right.\end{array}$ \\
\hline & Solan & 6.85 \\
\cline { 2 - 3 } & Bilaspur & 7.34 \\
\cline { 2 - 3 } & Kangra & 7.16 \\
\cline { 2 - 3 } & Hamirpur & 8.53 \\
\cline { 2 - 3 } & Una & 7.87 \\
\cline { 2 - 3 } & CD(0.05) & 7.76 \\
\hline \multirow{4}{*}{ Uttrakhand } & Babu Gate FRI & 7.45 \\
\hline & Haridwar & 8.14 \\
\cline { 2 - 3 } & Rishikesh & 6.73 \\
\cline { 2 - 3 } & Pantnagar & 8.02 \\
\cline { 2 - 3 } & Nainital & 7.73 \\
\cline { 2 - 3 } & CD(0.05) & 4.76 \\
\hline
\end{tabular}


Table.2 Authentication of rhizobia isolated from root nodules of Dalbergia sissoo

\begin{tabular}{|c|c|c|c|c|c|c|}
\hline \multicolumn{7}{|c|}{ Himachal Pradesh } \\
\hline $\begin{array}{l}\text { S. } \\
\text { No }\end{array}$ & Isolates & $\begin{array}{l}\text { Congo } \\
\text { Red } \\
\text { Test }\end{array}$ & $\begin{array}{l}\text { Bromothymol } \\
\text { Blue Test }\end{array}$ & $\begin{array}{l}\text { Growth in } \\
\text { Hofer's } \\
\text { alkaline broth }\end{array}$ & $\begin{array}{c}\text { Ketolactose } \\
\text { Test }\end{array}$ & $\begin{array}{c}\text { Infectivity test } \\
\text { (Nodule formation) }\end{array}$ \\
\hline 1 & $\mathrm{DSN}_{1}$ & - & Alkaline producer & No growth & - & Absent \\
\hline 2 & $\mathrm{DSN}_{2}$ & - & Acid producer & No growth & - & Present \\
\hline 3 & $\mathrm{DSN}_{3}$ & - & Acid producer & No growth & - & Present \\
\hline 4 & $\mathrm{DSN}_{4}$ & - & Acid producer & No growth & - & Present \\
\hline 5 & $\mathrm{DSN}_{5}$ & - & Acid producer & No growth & - & Absent \\
\hline 6 & $\mathrm{DSN}_{6}$ & - & Acid producer & No growth & - & Absent \\
\hline 7 & $\mathbf{D S N}_{7}$ & - & Acid producer & No growth & - & Present \\
\hline 8 & $\mathrm{DSN}_{8}$ & - & Alkaline producer & No growth & - & Present \\
\hline 9 & $\mathrm{DHL}_{1}$ & - & Acid producer & No growth & - & Present \\
\hline 10 & $\mathrm{DHL}_{2}$ & - & Acid producer & No growth & - & Present \\
\hline 11 & $\mathrm{DHL}_{3}$ & - & Acid producer & No growth & - & Absent \\
\hline 12 & $\mathrm{DHL}_{4}$ & - & Alkaline producer & No growth & - & Absent \\
\hline 13 & $\mathrm{DHL}_{5}$ & - & Acid producer & No growth & - & Present \\
\hline 14 & $\mathrm{DHL}_{6}$ & - & Alkaline producer & No growth & - & Present \\
\hline 15 & $\mathbf{D K A}_{1}$ & - & Alkaline producer & No growth & - & Present \\
\hline 16 & $\mathbf{D K A}_{2}$ & - & Acid producer & No growth & - & Present \\
\hline 17 & $\mathbf{D K A}_{3}$ & - & Acid producer & No growth & - & Present \\
\hline 18 & $\mathbf{D K A}_{4}$ & - & Acid producer & No growth & - & Absent \\
\hline 19 & $\mathbf{D K A}_{5}$ & - & Acid producer & No growth & - & Absent \\
\hline 20 & DKA $_{6}$ & - & Alkaline producer & No growth & - & Present \\
\hline 21 & $\mathbf{D K A}_{7}$ & - & Acid producer & No growth & - & Present \\
\hline 22 & $\mathbf{D K A}_{8}$ & - & Acid producer & No growth & - & Present \\
\hline 23 & DBD $_{1}$ & - & Acid producer & No growth & - & Present \\
\hline 24 & $\mathrm{DBD}_{2}$ & - & Acid producer & No growth & - & Absent \\
\hline 25 & $\mathbf{D B D}_{3}$ & - & Acid producer & No growth & - & Absent \\
\hline 26 & $\mathrm{DBD}_{4}$ & - & Acid producer & No growth & - & Present \\
\hline 27 & DBD $_{5}$ & - & Acid producer & No growth & - & Present \\
\hline 28 & DBD $_{6}$ & - & Acid producer & No growth & - & Present \\
\hline 29 & $\mathbf{D B D}_{7}$ & - & Acid producer & No growth & - & Present \\
\hline 30 & DUB $_{1}$ & - & Acid producer & No growth & - & Present \\
\hline 31 & $\mathbf{D U B}_{2}$ & - & Alkaline producer & No growth & - & Absent \\
\hline 32 & $\mathrm{DUB}_{3}$ & - & Acid producer & No growth & - & Present \\
\hline 33 & $\mathbf{D U B}_{4}$ & - & Acid producer & No growth & - & Absent \\
\hline 34 & DUB $_{5}$ & - & Acid producer & No growth & - & Present \\
\hline 35 & DUB $_{6}$ & - & Alkaline producer & No growth & - & Present \\
\hline 36 & DUB $_{7}$ & - & Acid producer & No growth & - & Present \\
\hline 37 & DUB $_{8}$ & - & Alkaline producer & No growth & - & Present \\
\hline 38 & DUB $_{9}$ & - & Alkaline producer & No growth & - & Absent \\
\hline
\end{tabular}


Table.3 Morphological, Biochemical characterization and Optimization of selected rhizobial isolates

\begin{tabular}{|c|c|c|c|c|c|c|c|c|c|c|c|c|c|c|}
\hline \multicolumn{15}{|c|}{ Morphological Characters } \\
\hline $\begin{array}{c}\text { Rhizobial } \\
\text { Isolates }\end{array}$ & $\begin{array}{l}\text { Colony } \\
\text { colour }\end{array}$ & Opacity & Form & Surface & Texture & \multicolumn{2}{|c|}{ Motility } & & hape & \multicolumn{2}{|c|}{ Arrangement } & Colour & $\begin{array}{l}\text { Gram's } \\
\text { reaction }\end{array}$ & $\begin{array}{l}\text { Endospore } \\
\text { staining }\end{array}$ \\
\hline DBD $_{1}$ & White & Opaque & Circular & Granular & Slimy & & + & & Rods & & ster/single & Pink & - & - \\
\hline \multicolumn{15}{|c|}{ Biochemical characters of selected rhizobial isolates } \\
\hline & $\begin{array}{c}\text { Indole } \\
\text { test }\end{array}$ & $\begin{array}{c}\text { Methyl- } \\
\text { Red } \\
\text { test }\end{array}$ & \begin{tabular}{|c|} 
Voges \\
Proskauer \\
test
\end{tabular} & \begin{tabular}{|c|} 
Hydrogen \\
sulphide \\
production
\end{tabular} & \multicolumn{2}{|c|}{$\begin{array}{c}\text { Catalase } \\
\text { test }\end{array}$} & \multicolumn{2}{|c|}{$\begin{array}{c}\text { Citrate } \\
\text { test }\end{array}$} & \multicolumn{2}{|c|}{$\begin{array}{c}\text { Starch } \\
\text { hydrolysis }\end{array}$} & $\begin{array}{c}\text { Cellulase } \\
\text { Test }\end{array}$ & $\begin{array}{c}\text { Casein } \\
\text { test }\end{array}$ & $\begin{array}{l}\text { Urease } \\
\text { test }\end{array}$ & $\begin{array}{c}\mathrm{NH}_{3} \\
\text { production }\end{array}$ \\
\hline DBD $_{1}$ & \multirow[b]{2}{*}{ Xylulose } & + & \multirow{2}{*}{ Sucrose } & \multirow{2}{*}{ Galactose } & \multicolumn{2}{|c|}{+} & \multicolumn{2}{|c|}{-} & & & - & - & \multirow[t]{2}{*}{+} & ++ \\
\hline $\begin{array}{c}\text { Carbohydrat } \\
\text { test }\end{array}$ & & Fructose & & & Maltc & & Mannit & & & & Glucose & Xylulose & & \\
\hline DBD $_{1}$ & + & + & + & + & \multicolumn{2}{|l|}{+} & \multicolumn{2}{|l|}{+} & - & & + & + & & \\
\hline & & & ptimizat & ion of co & ndition & for & r sele & cte & d rh & zob & ial isolate & & & \\
\hline pH & DBD $_{1}$ & Temp & erature $\left({ }^{\circ} \mathbf{C}\right)$ & DBD $_{1}$ & $\begin{array}{r}\text { Inct } \\
\text { per }\end{array}$ & oatio & & & $\mathbf{D B D}_{1}$ & & $\begin{array}{c}\mathrm{NaCl} \\
\text { concentratio } \\
(\%)\end{array}$ & & DBD $_{1}$ & \\
\hline 4.0 & - & & 20 & + & & 0 & & & - & & 0 & & + & \\
\hline 5.0 & + & & 25 & ++ & & 2 & & & - & & 0.25 & & + & \\
\hline 6.0 & + & & 30 & ++ & & 4 & & & + & & 0.5 & & + & \\
\hline 7.0 & ++ & & 35 & + & & 8 & & & ++ & & 0.75 & & + & \\
\hline 8.0 & + & & 40 & + & & 2 & & & ++ & & 1 & & + & \\
\hline 9.0 & - & & 45 & - & & 6 & & & + & & 2 & & + & \\
\hline & & & & & & 20 & & & + & & 3 & & + & \\
\hline & & & & & & & & & & & 4 & & + & \\
\hline & & & & & & & & & & & 5 & & - & \\
\hline
\end{tabular}

Biochemical characterization of selected isolates

The results presented in (Table 3) indicated that the rhizobial isolate was positive for methyl red test, catalase test, urease test, ammonia production test, and negative for Indole test, voges Proskauer test, hydrogen sulphide production, citrate test, cellulase and casein test. In case of carbon utilization, the isolate was able to ferment xylulose, sucrose, galactose, maltose, mannitol fructose except lactose.

The present results are in confirmatory with those of Menna et al., (2006) also characterized strains based on morphophysiological characters. Kumar et al., (2017a) who also observed similar morphological characteristic for the genus
Rhizobium. Surange et al., (1997) characterized Rhizobium strain with respect to carbon utilization (including sugars). Batzli $e t$ al., (1992) also characterized and identified 11 isolates as Rhizobium based upon their morphological characters. The utilization of diverse carbon sources by bacterial isolates might indicate their metabolic and ecological diversity suggesting their use as biofertiliser/ biocontrol agent (Deng et al., 2011; Fitriyah et al., 2013; Mantilla-Afanador et al., 2017).

\section{Physiological characterization of selected isolates}

The results presented in Table 3 indicated the growth of selected isolate at a $\mathrm{pH}$ 4.0-9.0, temperature of $20-45^{\circ} \mathrm{C}$, incubation period of $0-120$ hrs and $\mathrm{NaCl}$ concentration of $0-5$ per cent. The isolate was able to grow at $\mathrm{pH}$ 
ranges between 5.0 and 8.0. However, was unable to grow at high acidic $\mathrm{pH}$ of 4.0 and alkaline $\mathrm{pH}$ at 9.0. The isolate was able to grow at the temperature range of $20-35^{\circ} \mathrm{C}$ and was unable to grow at temperature of $45^{\circ} \mathrm{C}$. The suitable salt concentration for its growth was found to be at most 5 per cent. Similar morphological, physiological and biochemical characters of rhizobial isolates have been reported by Lalitha and Immanuel (2013) and Rasool et al., (2015). Pawar et al., (2014) reported that nodulating bacteria isolated from soybean root nodules showed good growth at temperature $36^{\circ} \mathrm{C}$ and $\mathrm{pH}$ 7.0. Datta et al., (2015) reported Rhizobium strains isolated from root nodules of Trifolium, Vigna radiate, Glycine max and Lens culinaris grew well at 6.0 and $7.0 \mathrm{pH}, 34^{\circ} \mathrm{C}$ temperature and 4 per cent salt concentration.

On the basis of morphological, physiological, biochemical characteristics and Bergey's Manual of Systematic Bacteriology (Claus and Berkeley, 1986) the isolate $\mathrm{DBD}_{1}$ was tentatively identified as Rhizobium species. Similar morphological, physiological and biochemical characteristics of rhizobial isolates have reported by Lalitha and Immanuel (2013), Rasool et al., (2015).

In conclusion, in the present study we isolated Rhizobium spp. from the root nodules of Dalbergia sissoo and resolute their ability for growth promoting factors. We obtained only two Rhizobium strains those are capable for fixing higher amount of nitrogen along with different growth promoting factors. Thus these strains may be applied in proficient nodulation of Dalbergia sissoo for biological nitrogen fixation as well as in afforestation programme.

\section{Acknowledgements}

The authors are thankful to the National Mission on Himalayas, G.B. Pant National Institute of Himalayan Environment and
Sustainable Development (GBPNIHESD), Kosi-Katarmal, Almora-263643 (Uttarakhand) for financial assistance of the project.

\section{Disclosure of potential conflicts of interest:}

N/A

\section{Funding}

National Mission on Himalayas, G.B. Pant National Institute of Himalayan Environment and Sustainable Development (GBPNIHESD), Kosi-Katarmal, Almora263643 (Uttarakhand)

\section{References}

Agrawal P K, Agrawal S, Singh U, Katiyar N and Verma S K. 2012. Phenotypic characterization of rhizobia from legumes and its application as a bioinoculant. Journal of Agricultural Technology 8: 681-92.

Balota E L and Chaves J C D. 2011. Microbial activity in soil cultivated with different summer legumes in coffee crop. Brazilian Archives of Biology and Technology 54: 35-44.

Batzli J M, Graves W R and Berkum P. 1992. Isolation and characterization of rhizobia effective with Maackia amurensis. Journal of the American Society for Horticultural Science 117: 612-16.

Bernaerts M J and Deley J A. 1963. A biochemical test for crown gall bacteria. Nature 197: 406-07.

Claus D and Berkeley R C W. 1986. Genus Bacillus. In: P.H.A. Sheath (Ed.), Bergey's Manual of Systematic Bacteriology, Vol. III. Williams \& Wilkins, Baltimore, pp. 1105-39.

Datta A, Singh R K and Kumar S. 2015. Isolation, characterization and growth of Rhizobium strains under optimum 
conditions for effective biofertilizer production. International Journal of Pharmacology Science 32: 199-08.

Deng Z S, Zhao L F, Kong Z Y, Yang W Q, Lindstrom K, Wang $\mathrm{E} T$ and Wei $\mathrm{G} \mathrm{H}$. 2011. Diversity of endophytic bacteria within nodules of the Sphaerophysa salsula in different regions of Loess Plateau in China. FEMS Microbiology Ecology 76: 463-75.

Deshwal V and Chaubey A. 2014. Isolation and characterization of Rhizobium leguminosarum from root nodule of Pisum sativum L. Journal of Academia and Industrial Research 2: 464-67.

Deshwal V K, Dubey R C and Maheshwari D K. 2003. Isolation of plant growth promoting strains of Bradyrhizobium (Arachis) sp. with biocontrol potential against Macrophomina phaseolina causing charcoal rot of peanut. Current Sciences 84:443-44.

Dipta B, Kirti S, Bhardwaj S, Gupta S and Kaushal R. 2017. Phosphate solubilising potential of Bacillus pumilus for the enhancement of cauliflower (Brassica olearacea var. botrytis L.). Ecology Environment and Conservation 23:1541-48.

Fitriyah D, Arimurti S and Senjarini K. 2013. Physiological and molecular characteristics of bacterial isolates from Bandealit Coastal Area of Indonesia. Journal of Biosciences 20:89-93.

Ghosh P K and Maiti T K. 2016. Structure of Extracellular Polysaccharides (EPS) Produced by rhizobia and their functions in Legume-Bacteria Symbiosis:-A Review. Achievements in the Life Sciences 10:136-43.

Hofer A W. 1935. Methods for distinguishing between legume bacteria and their most common contaminant. Journal of the American Society of Agronomy 27:22830.

Kumar R, Dash D, Gupta S B, Soni R and
Singh A K. 2017a. Inoculation effects of Rhizobium and phosphorous solubulizing bacteria on growth and nodulation of Acacia nilotica. International Journal of Current Microbiology and Applied Sciences 6:2444-53

Lalitha S and Immanuel S P. 2013. Biochemical characterization of Rhizobium and its impact on black gram and green gram plants. International Journal of Current Science 9:1-6

Mahmood A and Athar M. 2008. Cross inoculation studies: response of Vigna mungo to inoculation with rhizobia from tree legumes growing under arid environment. International Journal of Environmental Science and Technology 5:135-39.

Mantilla-Afanador J G, Gallego L F A and Salamanca J A. 2017. Metabolic diversity of the microbial community and endophytic nitrogen-fixing bacteria in the rhizosphere. International Journal of Agriculture and Environmental Research 3:2493-10.

Menna P, Hungria M, Barcellos F G, Bangel E V, Hess PN and Martinez-Romero E. 2006. Molecular phylogeny based on the 16S rRNA gene of elite rhizobial strains used in Brazilian commercial inoculants. Systematic and Applied Microbiology 29:315-32.

Norris D O. 1965. Acid production by Rhizobium: a unifying concept. Plant and Soil 22:143-66.

Pawar V A, Pawar P R, Bhosale A M and Chavan S V. 2014. Effect of Rhizobium on seed germination and growth of plants. Journal of Academia and Industrial Research 3:84-88.

Rasool S, Sharma B and Rasool S. 2015. Isolation and characterization of Rhizobium sp. from a wild legume from BGSBU campus of District Rajouri, 
J\&K. International Journal of Agricultural Sciences 5:407-13.

Surange S, Wollum Ii A G, Kumar N and Nautiyal C S. 1997. Characterization of Rhizobium from root nodules of leguminous trees growing in alkaline soils. Canadian Journal of Microbiology 43:891-94.

Vincent J M. 1947. Distortion of fungal hyphae in the presence of certain inhibitors. Nature 150: 850-67.

Wieland G, Neumann R and Backhaus H. 2001. Variation of microbial communities in soil, rhizosphere and rhizoplane in response to crop species, soil type, and crop development. Applied and Environmental
Microbiology 67:5849-54.

Zahran H H, Abdel F M, Yasser M M, Mahmoud AM and Bedmar E J. 2012. Diversity and environmental stress responses of rhizobial bacteria from Egyptian grain legumes. Australian Journal of Basic and Applied Science 6:571-83.

Zhou J, Jiang X, Wei D, Zhao B, Ma M, Chen S, Cao F, Shen D, Guan D and Li J. 2017. Consistent effects of nitrogen fertilization on soil bacterial communities in black soils for two crop seasons in China. Scientific Reports $7: 3267$.

\section{How to cite this article:}

Meenakshi Dhiman, Vinay Kumar Dhiman, Neerja Rana and Bhawna Dipta. 2019. Isolation and Characterization of Rhizobium Associated with Root Nodules of Dalbergia sissoo. Int.J.Curr.Microbiol.App.Sci. 8(03): 1910-1918. doi: https://doi.org/10.20546/ijcmas.2019.803.227 